\title{
COMBINATION PATENTS: THE RIGHT TO PROHIBIT SALES OF REPLACEMENT PARTS*
}

THE scope of combination patents, long a source of confusion in patent law, has again come before the Supreme Court, ${ }^{1}$ furnishing the first opportunity to assess the impact of two major upheavals in this area in recent years. Under the patent act, a patentee is granted the exclusive right to make, use, or sell his patented invention in the United States for seventeen years. ${ }^{2}$ A patent may cover a combination of elements, unpatentable in themselves, which when combined produce new and useful results. ${ }^{3}$ Technically, such a patent is infringed only when the combination as a whole is made, used, or sold. ${ }^{4}$ Presumptively therefore, the patentee would have no right to control the sale of an unpatented component used in the invention. Further, it might be argued that control over component parts would result in a restraint upon competition greater than that contemplated by the patent grant. ${ }^{5}$ Denial of such control, however, may in some circumstances frustrate the policy of the patent laws by substantially destroying the value of the patentee's monopoly. The unrestricted sale of components to consumers would enable consumers to, in effect, reconstruct wornout devices instead of turning to the patentee for a new machine. The patentee would, of course, have a remedy against the purchaser for "making" the patented device, but this remedy is largely theoretical. There are generally so many consumers, each of whom has committed an economically trifling infringement, that a suit to prevent sale of components may be the only practical means of preventing unauthorized reconstruction. ${ }^{6}$ Combination

*Aro Mfg. Co. v. Convertible Top Replacement Co., 270 F.2d 200 (1st Cir. 1959), ccrt. granted, 362 U.S. 902 (1960).

1. Ibid.

2. 35 U.S.C. $\S 154$ (1958) ; see U.S. Const. art. 1, § 8. For requirements of patentability, see 35 U.S.C. $\$ \$ 101-03$ (1958) ; Reviser's Note, 35 U.S.C. $\$ 103$ (1958); AMdur, Patent Fundamentals 53-55 (1941); Toularin, Handbook of Patents 48-69 (2d ed. 1954) [hereinafter cited as TouLMIN].

3. There must be new and useful coaction between the several elements in a patentable combination. If one merely improves some element of a combination, a patent may be secured for the new element but not for the entire combination even though it may give improved results, because the elements are coacting in an "old" way. Bassick Mfg. Co. v. Hollingshead Co., 298 U.S. 415 (1936). See generally Toularin, at 76-77; AMrdur, Patent FundaMentals 16\$-219 (1941). Compare 35 U.S.C. \$§ 101, 161, 171 (1958) (other patents).

4. "[W] here a patent is for a combination merely, it is not infringed by one who uses one or more of the parts, but not all, to produce the same results, either by themselves, or by the aid of other devices." Wallace v. Holmes, 29 Fed. Cas. 74, 80 (No. 17100) (C.C.D. Conn. 1871), citing Prouty v. Ruggles, 41 U.S. (16 Pet.) 336, 341 (1842).

5. Cf. Millner v. Schofield, 17 Fed. Cas. 392, 393 (No. 9609a) (C.C.W.D. Va. 1881).

6. See Roberts, Contributory Infringement of Patent Rights, 12 HARv. L. Rev. 35, 39-40 (1898). 
patents have been construed, therefore, to give the patentee some control over the sale of unpatented components.

The patentee's remedy against suppliers of component parts has been based on the theory of "contributory infringement," a doctrine developed through the application of general tort principles to the patent laws: if the use of the item sold would result in the tort of direct infringement by the purchaser, the supplier is treated as a joint tort-feasor. ${ }^{7}$ This doctrine applied to the parts maker who sold to an unauthorized manufacturer of new devices, as well as to makers of replacement parts for reconstruction. Although the doctrine as originally expounded was applicable only if the supplier knew that the component was to be used in the patented combination, ${ }^{8}$ such knowledge was presumed if the element sold had no other significant use. ${ }^{9}$ More important was the requirement of a "direct infringement." 10 Even if the component was made especially for a patented device, the patentee must prove that its use by the consumer would constitute making, using, or selling the device in violation of his patent monopoly. To identify direct infringement in replacement sales cases, courts originally looked to the contract, express or implied, between the patentee and

7. See, e.g., Rumford Chem. Works v. New York Baking Powder Co., 136 Fed. 873 (S.D.N.Y. 1905) ; Thomson-Houston Elec. Co. v. Ohio Brass Co., 80 Fed. 712 (6th Cir. 1897) ; Thomas, The Law of Contributory Infringement, 21 J. PAT. OFF. Soc'y 811, 81728 (1939) (citing cases).

Restatenent, ToRTs $\$ 876$ (1939) states that:

For harm resulting to a third person from the tortious conduct of another, a person is liable if he (a) orders or induces such conduct, knowing of the conditions under which the act is done or intending the consequences which ensue, or (b) knows that the other's conduct constitutes a breach of duty and gives substantial assistance or encouragement to the other so to conduct himself .... .

(Emphasis added.) See Thomas-Houston Elec. Co. v. Ohio Brass Co., 80 Fed. 712, 721 (6th Cir. 1897) ; Matthews, Contributory Infringement and The Mercoid Case, 27 J. PAт. OFF. Soc'y 260, 263-64 (1945).

The earliest use of the doctrine was in Wallace v. Holmes, 29 Fed. Cas. 74 (No. 17100) (C.C.D. Conn. 1871) (selling burner for patented lamp combination). The modern term, "contributory infringer," was not used until Snyder v. Bunnell, 29 Fed. 47 (S.D.N.Y. 1886).

8. If the article sold was capable of noninfringing uses, the plaintiff had the burden of showing specific intent. Thomson-Houston Elec. Co. v. Ohio Brass Co., 80 Fed. 712, 723 (6th Cir. 1897). Mere proof of knowledge that the element was to be used in a particular device was sufficient to prove the requisite intent. E.g., Cutler-Hammer Mfg. Co. v. Union Elec. Mfg. Co., 147 Fed. 266, 275 (E.D. Wis. 1906); Whitney v. New York Scaffolding Co., 243 Fed. 180, 185 (8th Cir. 1917). Contra, Millner v. Schofield, 17 Fed. Cas. 392 (No. 9609a) (C.C.W.D. Va. 1881).

9. Thomson-Houston Elec. Co. v. Ohio Brass Co., stupra note 8, at 723; Wallace v. Holmes, 29 Fed. Cas. 74, 80 (No. 17100) (C.C.D. Conn. 1871).

For the current status of the knowledge requirement, see note $40 \mathrm{infra}$.

10. Radio Corp. of America v. Andrea, 79 F.2d 626 (2d Cir. 1935) ; Bullock Elec. \& Mfg. Co. v. Westinghouse Elec. \& Mfg. Co., 129 Fed. 105 (6th Cir. 1904). 
the purchaser of his invention. ${ }^{11}$ If the machine was sold without restrictions, the purchaser was assumed to have the right to make any repairs necessary to his full use of the device. ${ }^{12} \mathrm{He}$ had not, however, acquired a license to make another machine. Thus, replacement of a component was held to constitute permissible "repair" when the machine's wearing or injury was "partial" 13 but a direct infringement by "reconstruction" if the machine "as a whole ... [was] so much worn out as to be useless." 14 This somewhat intuitive distinction was also verbalized by stating that replacements were permissible repairs so long as the device did not lose its "original identity." 15

In the absence of express contractual limitations on the purchaser's right to repair, courts attempted to establish criteria to distinguish between repair and reconstruction. The perishability of the parts relative to "the machine as a whole" was emphasized by the Supreme Court and many lower court decisions. For example, the patentee was not allowed to prevent replacement of razor blades in a safety razor, ${ }^{16}$ needles in a hypodermic syringe, ${ }^{17}$ or cutting blades in a planing machine.18 In some cases, however, a part, such as the filament in a light bulb, may be so important that, regardless of its perishability, it is substantially the whole device. Courts then applied the "vital element" test which looks to the importance of the element with respect to the inventiveness it rep-

11. Heyer v. Duplicator Mfg. Co., 263 U.S. 100, 102 (1923) ("we have only to establish the construction of a bargain on principles of common sense"); Morgan Gardner Elec. Co. v. Buettner \& Shelburne Miach. Co., 203 Fed. 490, 493 (7th Cir. 1913).

12. Wilson v. Simpson, 50 U.S. (9 How.) 109, 122 (1850) ; F. F. Slocomb \& Co. v. A. C. Layman Mach. Co., 227 Fed. 94, 97 (D. Del. 1915) (right to make repairs "in absence of a stipulation to the contrary").

Theoretically, the patentee could, if he wished, negative the presumed intent to permit repair by an express contract provision prohibiting some or all replacements. Cf. CottonTie Co. v. Simmons, 106 U.S. 89 (1882). But cf. Morgan Envelope Co. v. Albany Perforated Wrapping Paper Co., 152 U.S. 425 (1894).

The contract approach was also used to tie-in sales of unpatented supplies. See Henry v. A. B. Dick Co., 224 U.S. 1 (1912) ; Heaton-Peninsular Button-Fastener Co. v. Eureka Specialty Co., 77 Fed. 288 (6th Cir. 1896). Dick was not overruled until Motion Picture Patents Co. v. Universal Film Mfg. Co., 243 U.S. 502 (1917). See notes 22 and 23 infra.

13. Wilson v. Simpson, 50 U.S. ( 9 How.) 109, 122 (1850).

14. Id. at 124 .

15. Goodyear Shoe Mach. Co. v. Jackson, 112 Fed. 146, 149 (1st Cir. 1901) ; Davis Elec. Works v. Edison Elec. Light Co., 60 Fed. 276, 279-80 (1st Cir. 1894); Wilson v. Simpson, 50 U.S. (9 How.) 109, 123 (1850). The purchaser who makes successive replacements, each of which would alone be permissible, until he has replaced virtually all of the elements, does not necessarily infringe; replacements are not to be treated cumulatively. Davis Elec. Works v. Edison Elec. Light Co., supra (dictum); see Cinema Patents Co. v. Craft Film Labs., Inc., 64 F.2d 42 (3d Cir. 1933); Brown, The Mannfacture and Sale of Unpatented Parts, 18 J. Pat. OfF. Soc'y 573, 596 (1936).

16. Gillette Safety Razor Co. v. Standard Safety Razor Co., 64 F.2d 6 (2d Cir.), cert. denied, 290 U.S. 649 (1933) (replacement of worn out blade in razor).

17. Payne v. Dickinson, 109 F.2d 52 (3d Cir.), cert. denied, 310 U.S. 637 (1940).

18. Wilson v. Simpson, 50 U.S. (9 How.) 108, 125 (1850). 
resents, its operational effectiveness, and its structural predominance. ${ }^{10}$ An additional factor sometimes mentioned secondarily is the economic value of the parts replaced relative to those remaining. ${ }^{20}$

The contract approach, however, assumed that the patentee could, by express restrictions, limit the purchaser's right to make replacements which would otherwise be permissible under the repair-reconstruction test. ${ }^{21}$ In effect, it allowed the patentee effectively to define the limits of his statutory monopoly by private contract. The contract approach was overruled, at least in part, in 1917 by the Supreme Court's decision in Motion Picture Patents Co. v. Universal Film $M f g . C_{0} .^{22}$ The Court refused to enforce license provisions which obligated the purchaser to use certain supplies which were not elements of the patented combination. The Court held that supplies not mentioned in the patent could not be monopolized by contract. ${ }^{23}$ The premise of this decision is that the statute rather than contract defined the right of the parties. As applied to replacement parts, the rationale of Motion Picture would have required courts to define the statutory grant of protection in order to decide whether a contractual restriction was within the grant of monopoly powers. Courts dealing with replacement parts, however, continued to speak in terms of the "bargain" between the parties, citing the older cases and applying the established repairreconstruction test. ${ }^{24}$ This would imply that the statutory right over component parts is limitless, and that the contract defines how much control was actually exerted by the patentee. In spite of their "bargain" language, however, courts squarely facing the issue ${ }^{25}$ have adopted the line drawn by the repair-reconstruction test as a definition of the statutory grant of control over parts. ${ }^{26}$ But

19. Courts have not defined precisely what is meant by "vital." They seem, however, to emphasize patentability and functional importance. See, e.g., Davis Elec. Works v. Edison Elec. Light Co., 60 Fed. 276, 281-82 (1st Cir. 1894) (replacement of filament in light bulb) ; Morrin v. Robert White Eng'r Works, 138 Fed. 68, 71-73 (E.D.N.Y. 1905) (replacement of tubes in steam generator consisting of a shell and tiers of generating tubes). But see General Motors Corp. v. Preferred Elec. \& Wire Corp., 79 F.2d 621, 623 (2d Cir. 1935) ("the gist or essence of the combination of mechanical elements lies in the combination as a whole"). In Automotive Parts Co. v. Wisconsin Axle Co., 81 F.2d 125, 127 (6th Cir. 1935), the court rejects the above tests in favor of a structural one:

[I]f the new parts so dominate the structural substance of the whole as to justify the conclusion that it has been made anew, there is a rebuilding or reconstruction; and conversely, where the original parts, after replacement, are so large a part of the whole structural substance as to preponderate over the new, there has not been a reconstruction but only repair.

20. See, e.g., Heyer v. Duplicator Mfg. Co., 263 U.S. 100, 102 (1923).

21. See note 12 supra.

22. Motion Picture Patents Co. v. Universal Film Mfg. Co., 243 U.S. 502 (1917) (plaintiff patentee's movie projectors sold with restriction that they were only to be used with its films).

23. Id. at $517-18$.

24. Heyer v. Duplicator Mfg. Co., 263 U.S. 100, 102 (1923).

25. Most cases do not face the issue because, in the absence of an express contract provision prohibiting repair, the repair-replacement test applies regardless of its basis. The choice arises only when the contract attempts to prohibit repairs not allowed by the test.

26. See Landis Machinery Co. v. Chaso Tool Co., 141 F.2d 800, 803 (6th Cir. 1944). 
even with the demise of the contract approach, the contributory infringement doctrine still appeared to give combination patentees considerable control over the sale of component parts. ${ }^{27}$

In addition to denying enforcement, courts applying the new doctrine penalized patentees who had attempted to expand their patent monopoly. Not only would the court refuse to enforce the contract, but it would also refuse to protect the patentee against infringement. This was the doctrine of "misuse"the patent law equivalent of "unclean hands."2s Perhaps the most extreme application of this doctrine is Morton Salt Co.v. G.S. Suppiger Co., ${ }^{29}$ in which the patentee was found to have extended his patent monopoly illegally by requiring licensees of its patented salt machine also to purchase its salt. The patentee was denied relief against a third party who had clearly infringed the patent by manufacturing and selling the entire salt machine without a license. ${ }^{30}$

In Mercoid Corp. v. Mid-Continent Inv. Co., ${ }^{31}$ the Supreme Court's application of the misuse doctrine made it clear that misuse constituted a substantial if not total restriction on the use of the contributory infringement doctrine. Mercoid seemed to expand the misuse doctrine by making it applicable to attempts to monopolize the sale of any component. The patentee held a combination patent for a furnace stoker system, but neither the patentee nor his exclusive licensee manufactured the entire unit. Instead, the licensee manufactured one important component, a stoker switch, and conditioned the right to make and install the stoker system upon purchase of its stoker switch. The defendant also made stoker switches, whose only use was in the patentee's stoker system. Since the purchasers of defendant's switches were not purchasers of the patentee's switches, they were unauthorized to make or use the stolier system; thus defendant's customers were guilty of direct infringement

See also Williams v. Hughes Tool Co., 186 F.2d 278, 287-91 (10th Cir. 1950) (Murrah, $J$, concurring in part and dissenting in part).

27. See generally, Wood, The Tangle of Mercoid Case Intplications, 13 Geo. WasH. L. REv. 61 (1944).

28. See Morton Salt Co. v. G.S. Suppiger Co., 314 U.S. 488 (1942) ; 2 PoMreroy, EQUiTy JURISPRUdence $\$ 397$ (5th ed. 1941). The doctrine was established in Carbice Corp. of America v. American Patents Dev. Corp., 283 U.S. 27 (1931). See also Leitch Mfg. Co. v. Barber Co., 302 U.S. 458 (1938) ; American Lecithin Co. v. Warfield Co., 105 F.2d 207 (7th Cir. 1939) ; B. B. Chem. Co. v. Ellis, 314 U.S. 495 (1942). These cases deal with attempts to condition a license to use a patented process on the purchase from the patentee of certain material used in its practice.

29. 314 U.S. 488 (1942).

30. The Morton case is perhaps an unreasonable extension of the "clean hands" doctrine. Generally, the doctrine is confined to misconduct "in regard to, or at all events connected with, the matter in litigation, so that it has in some measure affected the equitable relations subsisting between the two parties, and arising out of the transaction . . ." 2 Poneroy, Egutty Jurisprudence $\$ 399$ (5th ed. 1941).

For a case applying misuse to an attempt to monopolize "repair" sales, see Landis Machine Co. v. Chaso Tool Co., 141 F.2d 800 (6th Cir. 1944).

31. 320 U.S. 661 (1944). 
whenever they installed a stoker system, and defendant's sales to them thereby became contributory infringement. So the Supreme Court assumed arguendo. ${ }^{32}$ When the patentee sued the defendant for contributory infringement, however, relief was denied on the ground that the patentee's stoker switchlicense agreements constituted misuse. The Court reasoned that the patent conferred only the right to monopolize the sale of the device as a unit, and that the patentee was attempting by these license agreements to monopolize the sale of stoker switches, an unpatented component. ${ }^{33}$ The Mercoid rationale indicates, however, that the "misuse" involved was not the restraint which the licensing arrangement imposed on defendant, for the Court admitted that if the patentee had not misused his patent, he would have been allowed to restrain the defendant from selling components. ${ }^{34}$ In other words, had the patentee or his licensee been engaged in the sale of the whole combination, they could have restrained defendant from manufacturing stoker switches. Rather, the Court's reasoning seems to indicate that the evil of the license was the way it benefited the patentee, giving him a monopoly over the sale of component parts instead of a monopoly over the sale of the unit as a whole. "Misuse" was defined, therefore, by looking to the nature of the reward which the patentee was attempting to obtain from his patent.

The Mercoid definition of misuse is not clearly separable from an analysis of the scope of the patent right itself. Traditionally, the patent right has been defined negatively, as the right to prevent others from making, using or selling a device. ${ }^{35}$ What the patentee gains from this right, or whether he gains anything, has not been considered crucial in determining whether someone else has infringed the patent. This has been so despite the underlying purpose of the patent right, which is to give the patentee some form of reward for his inventiveness. ${ }^{36}$ The misuse doctrine, as explained in Mercoid, carries the idea of a patent right to its logical conclusion by asking the question not asked by the infringement doctrine-Is the reward being obtained by the patentee the kind of reward which the patent laws intended him to enjoy? Thus, the "misuse" doctrine is not really separable from the doctrine of infringement, but is merely a more discriminating application of the purposes underlying it.

The Mercoid decision, and particularly its dicta, ${ }^{37}$ caused considerable con-

32. Id. at 668 .

33. Id. at $666-67$.

34. Id. at 668 .

35. See Bloomer v. McQuewan, 55 U.S. (14 How.) 539, 548 (1852) ("The franchise which the patent grants consists altogether in the right to exclude everyone from making, using, or vending the thing patented, without the permission of the patentee.") ; McCormick v. Talcott, 61 U.S. (20 How.) 402, 405 (1857).

36. For discussion of the need for and benefits derived from the patent system, see Temporary National Economic Committee Hearings, pt. 3, at 837, 839-43, 857-59 (1939); Yungblut, Dynamic Aspects of the Patent System, 28 J. Pat. OfF. Soc'y 18 (1946); Ward, The United States Patent System, 35 J. PAT. OfF. Soc'x 789, 789-99 (1953).

37. Justice Douglas seemed to overrule Leeds \& Catlin Co. v. Victor Talking Mach. Co., 213 U.S. 301 (1909), a classic contributory infringement case, saying:

[The case] is authority for the conclusion that he who sells an unpatented part of a combination patent for use in the assembled machine may be guilty of contributory 
fusion, leading courts to wonder what if anything was left of the contributory infringement doctrine. ${ }^{38}$ In response to this uncertainty, Congress included Section 271 in the 1952 Patent Act. ${ }^{39}$ This section gives statutory recognition to the previous common law doctrine of contributory infringement, stating in general the common law elements of that action. ${ }^{40}$ Appropriately, the restric-

infringement. The protection which the Court in that case extended to the phonograph record, which was an unpatented part of the patented phonograph, is in substance inconsistent with the view which we have expressed in this case. . . .

The result of this decision, together with those which have preceded it, is to limit substantially the doctrine of contributory infringement. What residuum may be left we need not stop to consider.

320 U.S. at $668-69$.

38. Stroco Prods. Inc. v. Mullenbach, 67 U.S.P.Q. 168 (S.D. Cal. 1944); Landis Mach. Co. v. Chase Tool Co., 141 F.2d 800, 801 (6th Cir. 1944) (dictum); Special Equip. Co. v. Coe, 324 U.S. 370 (1945) (dictum). Contra, Hall v. Montgomery Ward \& Co., 57 F. Supp. 430, 437-38 (N.D. W.Va. 1944) ; Jordan v. Hemphill Co., 180 F.2d 457, 46162 (4th Cir. 1950).

One writer postulates that the holding itself may outlaw contributory infringement suits, see Wood, The Tangle of Mercoid Case Implications, 13 Geo. WASH. L. Rev. 61, $71-73$ (1944). But see Diggins, The Patent-Antitrust Problem, 53 Micr. L. Rev. 1093, 1113 (1955). See generally Mathews, Contributory Infringement and The Mercoid Case, 27. J. Pat. Off. Soc'y 260 (1945).

39. 35 U.S.C. $\$ 271$ (1958). See Hearings Before the House Committee on the Judiciary, 82d Cong., 1st Sess., ser. 9, at 159 (1951) [hereinafter cited as Hearings, ser. 9], (statement of Mr. Rogers, Congressman from Colorado) :

Then in effect this recodification ... would point out to the court, at least that it was the sense of Congress that we remove this question of confusion as to whether contributory infringement existed at all, and state in positive law that there is such a thing....

See also H.R. REP. No. 1923, 82d Cong., 2d Sess. 9 (1952) ; Rich, Infringement under Section 271 of the Patent Act of 1952, 21 Geo. WASH. L. Rev. 521, 534-36 (1953).

40. Before the 1952 Act, neither direct nor contributory infringement were defined by statute. 35 U.S.C. $\$ 271$ (c) (1958) reads, in full:

Whoever sells a component of a patented machine, manufacture, combination or composition, or a material or apparatus for use in practicing a patented process, constituting a material part of the invention, knowing the same to be especially made or especially adapted for use in an infringement of such patent, and not a staple article or commodity of commerce suitable for substantial non-infringing use, shall be liable as a contributory infringer.

The one modification in the common law doctrine is the treatment of sales of staple articles. Under the statute, unlike the preexisting case law, see notes 7-9 supra and accompanying text, one can never be held liable for the sale of a staple.

The material part requirement, enacted to prevent patentees from transforming staple articles into unique elements by non-functional alterations, Hearings, ser. 9, at 157, would seem to require only that the component embody part of the novelty of the invention, id. at 154 .

The knowledge requirement is ambiguous. It has been construed not to require that the defendant know that the intended use of the part constituted infringement, Freedman v. Friedman, 242 F.2d 364 (4th Cir. 1957). Imposition of a more strict proof requirement would represent an unintended departure from previous case law. See Thomson-Houston Elec. Co. v. Ohio Brass Co., 80 Fed. 712, 723 (6th Cir. 1897) ; Hearings, ser. 9, at 164, 175. 
tive effect of Mercoid was not dealt with in the definition of infringement but in a separate subsection concerned solely with misuse. Section 271 (d) provides

No patent owner otherwise entitled to relief for infringement or contributory infringement of a patent shall be denied relief or deemed guilty of misuse or illegal extension of the patent right by reason of his having done one or more of the following: (1) derived revenue from acts which if performed by another without his consent would constitute contributory infringement of the patent; (2) licensed or authorized another to perform acts which if performed without his consent would constitute contributory infringement of the patent; (3) sought to enforce his patent rights against infringement or contributory infringement.

Subsection (3) has been interpreted to mean only that a contributory infringement suit cannot, per se, be misuse. ${ }^{41}$ Subsections (1) and (2) deal with the problem raised by the Mercoid case. Some commentators have argued that these subsections do not reverse the holding in Mercoid. Focusing on the fact that the statute allows patentees to "derive revenue" from the sale of component parts rather than saying forthrightly that patentees may control the sale of components, the commentators suggest that the statute merely permits a patentee to sell components competitively with other suppliers. ${ }^{42}$ Thus if the patentee does not wish to manufacture the whole device, he can only sell unrestricted licenses to make the device and then offer components to his licensees in competition with other component-makers. This analysis, however, does not make sense when applied to subsection (2). The statute permits the patentee to "license" or "authorize" others to do the same acts which he himself is permitted to do by subsection (1). If the only act permitted by subsection (1) is the sale of components in competition with unlicensed suppliers, the "Iicense" language is meaningless. Of what possible use is a "license" to compete when anyone can compete without a license? In order to give significance to the word "license," it must be assumed that the right of the patentee being licensed is somehow exclusive-that another supplier could not sell the component without the patentee's permission. If this is the case, both subsections must allow the patentee an exclusive right to sell components, precisely the type of monopoly struck down by Mercoid. The legislative history tends to support this conclusion; the Mercoid case was given by one draftsman as the fact situation covered by subsection (2)..$^{43}$

41. Hearings Before the House Committee on the Judiciary, 81st Cong., 1st Sess., ser. 17, at 79 (1949) [hereinafter cited as Hearings, ser. 17].

42. See Note, 66 Harv. L. Rev. 909, 916-18 (1953); Comment, 55 Mich. L. Rev. 1151, 1157-61 (1957). But see Schramm, The Relationship of the Patent Act of 1952 to the Antitrust Lazes, 23 Geo. WAsh. L. Rev. 36, 61-62 (1954).

43. Hearings, ser. 17, at 67 (statement of Mr. Rich, a member of the patent bar and one of the principal authors of $\$ 271$ ):

The exception which we wish to make to the misuse doctrine would reverse the result in the Mercoid case.

Hearings, ser. 9, at 174 (statements by Mr. Rich) ; see Hearings Before the House Com- 
In terms of the Mercoid misuse doctrine, what subsections (1) and (2) do is to redefine and expand the rewards which a patentee can legitimately derive from his combination patent. To the extent that some rewards may still not be permitted, however, the misuse doctrine would still apply, and patentees who seek monopolies outside the scope of this new grant would still be denied relief. Closer examination of the statute is required, therefore, to determine exactly what rewards beyond a monopoly over sales of the whole unit were added by the 1952 Act.

The language of the statute permits the patentee to monopolize the sale of a component if sale of that component by another would constitute infringement. There are two kinds of sales which can constitute infringement-sales of a component to one who is making a new device, and sales of a replacement part to the owner of a device for the purpose of "reconstruction." 44 The statute seems clearly intended to permit a monopoly over sales for the construction of a new device, since this is the nature of the Mercoid monopoly which the statute seeks to validate. ${ }^{45}$ Whether a monopoly over replacement part sales is also permitted is less certain.

The issue of a replacement part monopoly was presented by the recent First Circuit case of Aro Mfg. Co. v. Convertible Top Replacement Co.46 The

mittec on the Judiciary, 80th Cong., 2d Sess., ser. 21, at 17-18 (1948) (statement by Mr. Kenyon, patent attorney).

One court has so interpreted the statute in dictum. Sola Elec. Co. v. General Elec. Co., 146 F. Supp. 625, 646-47 (N.D. I1l. 1956). For a discussion of other cases dealing inconclusively with this issue, see Comment, 3 VIrL. L. Rev. 355 (1958).

44. These are the two infringement situations established by the case law. See, e.g., Wallace v. Holmes, 29 Fed. Cas. 74 (No. 17100) (C.C.D. Conn. 1871); Davis Elec. Works v. Edison Elec. Light Co., 60 Fed. 276 (1st Cir. 1894).

45. It might be argued that the patentee's licensing arrangement was also an attempt to monopolize replacement sales. The patentee's advertisement that the "right to use" the patented system was "only granted to the user" when its switches were purchased and used in the system is ambiguous, 320 U.S. at 663 . The lower courts found, however, that royalties had never been received on anything but switches used in complete installation of the unit, 133 F.2d at 811, indicating that only the more limited monopoly was being sought.

But in either case it is probable that the "Mercoid situation" which the drafters of the 1952 Act had in mind and intended to legalize was the monopolization of components for use in new units. This seems the case for two reasons. First, the replacement monopoly issue does not seem to have arisen in Mercoid; because the defendant did not argue that any of its sales were for permissible repair, the patentee's practice with respect to such sales was not directly relevant and does not seem to have been noticed or taken into account. There is one reference in the Circuit Court's opinion to the possibility that some of defendant's sales might be for repair and replacement, but the court dismisses these as non-infringing, $133 \mathrm{~F} .2 \mathrm{~d}$ at $808-09$. Compare the explicit attempt to monopolize both original and replacement sale of parts in Landis Mach. Co. v. Chaso Tool Co., 141 F.2d 800 (6th Cir. 1944). Also, the legislative history indicates, if only by negative inference, that the drafters were not consciously concerned with replacement sales. They are mentioned only a few times in the Hearings, incidentally and not in reference to misuse, Hearings, ser. 17, at 46, 69; Hearings, ser. 9, at 153.

46. 270 F.2d 200 (1st Cir. 1959), cert. granted, 362 U.S. 902 (1960). 
patented combination in question was a convertible top unit with certain automatic features which made it possible for the car owner to raise and lower the top without getting out of the car. The patentee and its licensees manufactured the entire unit for installation on new automobiles. They also made and sold replacements for the original fabric portion of the top, which normally wore out long before the other mechanical elements. The defendant, Aro, also manufactured the fabric portion, which was specially designed to fit the other features of the patentee's unit. Defendant's fabric part was advertised and sold as a replacement for the original. The court of appeals affirmed the district court's finding that defendant's sales constituted contributory infringement; it used the old common law contributory infringement cases to interpret section 271 (c), concluding that replacement of the fabric part was "reconstruction" rather than "repair." 47 Certiorari has been granted by the Supreme Court.48

The Circuit Court did not discuss the issue of whether the 1952 statute permits patentees to monopolize the sale of replacement parts, but the finding for the plaintiff implicitly assumes that it does. The language of the statute would support this view, for it allows the patentee to monopolize any sale which, if made by another, would constitute infringement, and does not qualify the word "infringement." 49 Apparently, no distinction is made between the two kinds of infringing sales. On the other hand, since patent monopolies are an exception to the public policy against monopolies and restraint of competition, they have, in recent years, been construed narrowly. Justice Jackson's opinion in Mercoid illustrates the attitude toward combination patents:

I think we should protect the patent owner in the enjoyment of just what he has been granted - an abstract right in an abstruse combination-worth whatever such a totality may be worth. I see no constitutional or statutory authority for giving it additional value by bringing into its monopoly all or any of the unpatentable parts. ${ }^{50}$

Although Mercoid's definition of the patent monopoly has been rejected by Congress, the rule of strict construction would still be applicable to the new definition under the 1952 act. Strictly construed, the monopoly grant of section 271(d) may not include replacement parts. If the traditional reconstruction test is applied to replacement sales to determine whether a patentee can monopolize such sales, the reward derived by the patentee may be significantly greater than the reward derived from a Mercoid-type monopoly over parts used for initial construction of whole units. In Mercoid, the patentee could have exercised its right to monopolize the sale of whole units (which would

47. 270 F.2d at 203-05. The statute itself adds little to the common law test of "infringement," except for the staple goods-material part limitation. See note 40 supra.

48. 362 U.S. 902 (1960).

49. See text at note 41 supra.

50. 320 U.S. 661,680 (1944) (dissenting on other grounds); $c f$. United States v. Univis Lens Co., 316 U.S. 241 (1942) (right to control resale price). 
have included, of course, a monopoly over stoker switches); it chose instead to monopolize only stoker switches. Arguably, the patentee restrained competition less than it could have. If the patentee were limited to this kind of reward from a replacement parts monopoly, he could only obtain a monopoly when there is a market for his invention, the entire unit. This situation will occur only when the consumer is willing to buy a whole unit if the part in question wears out-for example, the sale of a filament for a burned out light bulb in place of the sale of a new bulb. But the "reconstruction" test would probably not limit the replacement parts monopoly to this extent. The finding of reconstruction in Aro is an example, for it is doubtful that a consumer would buy an entire convertible top mechanism every time the fabric wore out-no one would buy a top under those conditions. ${ }^{51}$ Even if Aro misapplied the traditional "new-machine" test," applying it, such as "degree of inventiveness," "structural dominance," and "operational effectiveness" do not directly relate to the existence of a demand for the whole unit. The criteria of "relative perishability" and "relative cost," while more relevant to the existence of such demand, seem to have been outweighed, at least in emphasis, by those criteria more oriented toward defending the essential inventiveness of the combination. ${ }^{53}$

The legislative history of section 271 indicates that Congress was not aware of the possibility that the present reconstruction doctrine might grant monopoly rights exceeding those sought in Mercoid. Mercoid was consistently pointed to as an example of the misuse doctrine and its unduly restrictive effect; replacement parts were mentioned but once in the hearings, and then not in connection with the misuse doctrine. ${ }^{54}$ It may be possible to conclude, therefore, that Congress was concerned only with the somewhat anomalous result in Mercoid. Thus section 271, viewed as a redefinition of the rewards a patentee may claim, might be construed not to apply to monopolies over the sale of replacement parts, despite its broad wording.

If this interpretation is accepted, it would appear that the Mercoid misuse doctrine still applies to attempts to monopolize replacement parts. But this approach would be unsatisfactory. First, since Mercoid prohibits all replacement parts monopolies, ${ }^{55}$ it would disallow those few monopolies in which the sale of the part might be said to be a substitute for the possible sale of the whole device. Thus the misuse doctrine might impinge on the statutory policy allowing monopolies over component parts sold in lieu of new units. The enjoyment of valid monopolies might also be restricted by the sometimes indis-

51. See 270 F.2d at 205.

52. The court articulated the distinction as the difference between "minor repair" and "major reconstruction." It found the fabric part not perishable, although it had a life of about three years in relation to the life of the mechanism, which was probably the life of the car. Ibid.

53. See generally notes $18-20$ supra and accompanying text.

54. See Hearings, ser. 9, at 153.

55. See text at note 34 sitpra. 
criminate sweep of the misuse doctrine. In at least one case it has been held to wipe out all patent protection once an invalid monopoly is attempted. ${ }^{\text {50 }}$

A better way to effectuate the statutory policy would be to redefine the reconstruction test to make it comport with the idea of permissible reward which may be culled from the interaction of Mercoid and the statute. The sale of a replacement part could be found infringing only when the patentee could reasonably have made the sale of a whole unit if no parts were available. The result in some of the reconstruction cases would fit this test. In one, the infringer was replacing filaments in burned out light bulbs, certainly a case where the sale of a new light bulb was natural. ${ }^{57}$ In another, a patented machine-and-supporting-legs combination was found "reconstructed" by the replacement of the machine alone. ${ }^{58}$ Making the change in this manner would enable courts to give section 271 as broad an application as its language seems to call for. Sales monopolies on both new and replacement parts could be permitted, but the latter only when the sale of the part meets the strictly limited "reconstruction" test. The existence of a demand for an entire new unit would require evidence that the price of the whole unit would be considered reasonable by consumers even though the useable life of the whole unit were equal to the life of the part in question. This test seems easiest to apply when the patentee manufactures original units. If he manufactures only original units, he may be able to show sales evidence of purchases when repair parts are not available. If, however, he manufactures both original units and replacement parts, the contrary inference can be drawn, ${ }^{50}$ although it would be left open to the plaintiff to show some reason for selling parts rather than new units. In the case where the patentee does not make the whole unit, the characterization of the disputed part will be more difficult. The criteria of relative perishability and cost, now sometimes mentioned in reconstruction cases, would seem most appropriate for this determination.

56. Morton Salt Co. v. G.S. Suppiger Co., 314 U.S. 488 (1942), discussed in text at note 29 sttpra.

57. Davis Elec. Works v. Edison Elec. Light Co., 60 Fed. 276 (1st Cir. 1894).

58. Pacific Steam Whaling Co. v. Alaska Packers' Ass'n, 100 Fed. 462 (9th Cir. 1900). See also Cotton Tie Co. v. Simmons, 106 U.S. 89 (1882).

59. The inference would be based on the presumption that a patentee would not be selling replacement parts only, if there were a true market for the whole unit. 